\title{
Milk Production of Dairy Cows Fed Wet Corn Gluten Feed During the Dry Period and Lactation ${ }^{1}$
}

\author{
P. J. Kononoff, ${ }^{* 2}$ S. K. Ivan, ${ }^{\star 3}$ W. Matzke, ${ }^{\star 4}$ R. J. Grant,† R. A. Stock,‡ and T. J. Klopfenstein ${ }^{\star}$ \\ ${ }^{*}$ Department of Animal Science, University of Nebraska, Lincoln 68583-0908 \\ †Miner Institute, Chazy, NY 12921 \\ $\ddagger$ Cargill Incorporated, Blair, NE 68008
}

\section{ABSTRACT}

An experiment was conducted with 36 primiparous and 40 multiparous Holstein cows to examine the effects of feeding wet corn gluten feed (WCGF) on 305d milk production, dry matter (DM) intake, body condition score (BCS), and health. The experimental treatments included: 1) control-WCGF not fed $(\mathrm{n}=27) ; 2)$ WCGF-L-cows received diets containing WCGF (38\% $\mathrm{DM}$ basis) during lactation ( $\mathrm{n}=23)$; and 3) WCGFDL-cows received diets containing WCGF (38\% DM basis) during the dry period and lactation $(n=26)$. During the dry period, cows consuming WCGF were observed to have a significant gain in BCS $(0.07 \pm 0.06)$ compared with a loss in BCS in cows fed the control $\operatorname{diet}$ (control $=-0.11 \pm 0.06$ and WCGF-L $=-0.04 \pm$ 0.06). During lactation, there were no differences by treatment on BCS. Cows consuming WCGF during lactation consumed more feed compared with the control: $25.4,23.8$, and $21.2 \pm 0.76 \mathrm{~kg} / \mathrm{d}$ for WCGF-L, WCGF$\mathrm{DL}$, and the control, respectively. Milk production was higher for cows consuming WCGF: 35.0, 34.7, and 31.1 $\pm 2.1 \mathrm{~kg} / \mathrm{d}$ for WCGF-L, WCGF-DL, and the control, respectively. No differences were found in either DM intake or actual milk yield between the WCGF-L and WCGF-DL treatments, indicating that prepartum diets did not influence lactational performance. The WCGF diets resulted in significant reductions in the concentration of milk fat (3.94, 3.74, and $4.15 \pm 0.08 \%$ for WCGF-L, WCGF-DL, and the control, respectively), but because total milk yield was increased, there were no differences in total milk fat yield. In addition, 3.5\% of fat-corrected milk tended to be affected by diet: $38.9,36.3$, and $34.7 \pm 1.93 \mathrm{~kg} / \mathrm{d}$ for

\footnotetext{
Received November 20, 2005.

Accepted February 9, 2006.

${ }^{1} \mathrm{~A}$ contribution of the University of Nebraska Agricultural Research Division, Lincoln, NE 68583. Journal Series No. 15050.

${ }^{2}$ Corresponding author: pkononoff2@unl.edu

${ }^{3}$ Current address: Department of Animal and Avian Sciences, University of Maryland, College Park, MD 20742.

${ }^{4}$ Current address: Matzke-Holtz-Nelson Dairy Consultants, Oshkosh, WI 54904.
}

WCGF-L, WCGF-DL, and the control, respectively. The increasing effect of DM intake and milk yield in cows consuming WCGF resulted in a similar efficiency of $3.5 \%$ fat-corrected milk production for all treatments, averaging $1.5 \pm 0.09$. Total protein yields were significantly higher for cows consuming WCGF diets during lactation: $1.15,1.10,1.00 \pm 0.06 \mathrm{~kg} / \mathrm{d}$ for WCGFL, WCGF-DL, and the control, respectively. These results indicate that diets may be formulated to contain as much as $37.5 \%$ WCGF (DM basis).

Key words: lactation, corn gluten feed, dairy

\section{INTRODUCTION}

The recent growth of the US milling industries has provided an economic stimulus for domestic agriculture. This growth has also resulted in an increased availability of feed by-products, such as corn distiller's grains and corn gluten feed (Schingoethe et al., 1999). A by-product of the wet milling industry, wet corn gluten feed (WCGF) is largely composed of corn bran and steep liquor but may also contain varying amounts of distiller's solubles, germ meal, and kernel screenings (Macken et al., 2004). According to the NRC (2001) feed library, WCGF typically contains $24 \%$ CP, $30 \%$ of which is undegradable in the rumen. Corn gluten feed also contains approximately 35\% NDF and low levels of lignin (2\%), and is a source of highly digestible fiber that may supply energy to the lactating dairy cow. Because WCGF contains a relatively low concentration of rapidly fermentable carbohydrates such as starch, these feeds supply energy without increasing the risk of ruminal acidosis (Wickersham et al., 2004).

A number of investigators have evaluated the effects on dairy cattle performance of replacing forages and concentrates with WCGF. Armentano and Dentine (1988) substituted corn and soybean meal with WCGF in rations containing a high proportion of alfalfa silage. Results suggested that WCGF could be included at $36 \%$ of the ration DM without affecting intake, milk production, or composition. More recently, VanBaale et al. (2001) observed that when cows were fed diets containing $20 \% \mathrm{WCGF}$, they consumed more DM and 
produced more milk than those consuming diets higher in alfalfa hay, corn silage, and corn grain. Observations in both of these studies were collected in shortterm crossover designs. In a study conducted over 15 wk, Schroeder (2003) observed that inclusion of WCGF at $0,15,30$, and $45 \%$ resulted in $3.5 \% \mathrm{FCM}$, increasing in a quadratic manner $(26.1,31.6,29.5,26.9 \mathrm{~kg})$. In an additional study conducted over 9 wk, Boddugari et al. (2001) demonstrated that a wet corn milling product similar to WCGF may be effective in diets for lactating dairy cows. When used to replace the concentrate, the product could be included at $45 \%$ of the ration DM and at over 60\% when used to replace corn and forage. In a feeding trial involving 30 cows, these investigators also reported that, on average, cows consumed less feed but produced over $5 \mathrm{~kg}$ more milk when the WCGF replaced 50\% of the concentrate and $30 \%$ of the forage of the control diet. These results suggest that the optimal inclusion level depends on the feedstuffs being substituted for, as well as other ingredients contained in, the ration.

For a dairy cow, the transition period is marked by a decrease in intake despite the energetic demand required for the onset of lactation. During this time, the inclusion of fibrous by-product feedstuffs has been demonstrated to increase DM intake (Ordway et al., 2002), thereby meeting the nutrient demands of maternal and fetal tissues and also facilitating the transition from gestation to lactation (Hayirli et al., 2003). Based on previous studies, we hypothesized that feeding a diet containing WCGF throughout the entire dry period and the subsequent lactation period would result in increased DMI and milk production compared with a control diet not containing WCGF. The objectives of this study were to examine the effects of replacing a portion of the ground corn, forage, and soybean meal with WCGF in the ration of periparturient and postparturient dairy cows to evaluate its effect on full lactational performance, intake, and body condition.

\section{MATERIALS AND METHODS}

\section{Diets, Animals, and Experimental Design}

Over a 2-yr period, 36 primiparous and 40 multiparous Holstein cows were assigned to a completely randomized design and were blocked according to age (primiparous or multiparous) and expected date of calving. During the dry period, cows were grouped by experimental treatment and fed in a group setting. During lactation, cows were housed in individual stalls and milked at 0730 and $1930 \mathrm{~h}$ and were injected with bST (Posilac, Monsanto, St. Louis, MO) following the manufacturer's directions. Cows were fed ad libitum at $0800 \mathrm{~h}$ to allow for approximately $5 \%$ refusal. The
Table 1. Chemical composition of wet corn gluten feed (WCGF) and corn silage (DM basis)

\begin{tabular}{lccccc}
\hline & \multicolumn{2}{c}{ WCGF } & & \multicolumn{2}{c}{ Corn silage } \\
\cline { 2 - 3 } Composition, \% & Mean & SD & & Mean & SD \\
\hline CP & 25.6 & 0.55 & 9.5 & 0.52 \\
Soluble CP, \% of CP & 50.7 & 2.94 & & 59.6 & 3.00 \\
NDF & 33.6 & 1.87 & & 41.9 & 2.50 \\
ADF & 10.0 & 1.36 & 25.5 & 1.76 \\
Ether extract & 3.53 & 0.27 & 3.1 & 0.30 \\
NFC $^{1}$ & 29.7 & 0.91 & & 40.1 & 2.76 \\
Ash & 7.58 & 1.00 & & 5.3 & 0.23 \\
Ca & 0.05 & 0.01 & & 0.32 & 0.04 \\
Mg & 0.43 & 0.03 & & 0.16 & 0.01 \\
P & 1.09 & 0.06 & & 0.23 & 0.03 \\
K & 1.53 & 0.07 & & 1.43 & 0.29 \\
\hline${ }^{1}$ Calculated by difference & $100-(\%$ & NDF $+\%$ CP $+\%$ fat $+\%$ ash $).$
\end{tabular}

experimental cows were cared for according to the guidelines stipulated by the University of Nebraska Animal Care Committee. At dry off, 77 cows were assigned to 1 of 3 treatments: 1) the control, in which no WCGF was fed during the dry period and lactation $(\mathrm{n}=27) ; 2)$ a TMR containing WCGF during lactation only (WCGF-L; $\mathrm{n}=23$ ); or 3) a TMR containing WCGF during both the dry period and lactation (WCGF-DL; $\mathrm{n}=27$ ). The chemical compositions of WCGF and corn silage are listed in Table 1 , and the prepartum and lactation diets are listed in Tables 2 and 3. Diets were formulated to maximize the inclusion of WCGF and replace ingredients that were high in fiber, protein, and energy. Formulation aims for the diets fed were to keep the concentration of CP similar and to ensure that the concentration of NDF and energy met or exceeded NRC (2001) recommendations. For diets fed during lactation, attempts were made to keep the concentration of bypass protein similar.

\section{Experimental Measures and Sample Analysis}

Samples of feeds were collected weekly and composited by weight monthly. Collected samples were immediately frozen $\left(-20^{\circ} \mathrm{C}\right)$ and stored for further analysis. Samples were then dried at $60^{\circ} \mathrm{C}$ in a forced-air oven and ground (1-mm screen, Wiley mill; Arthur H. Thomas Co., Philadelphia, PA). Ground samples were also analyzed for DM $\left(100^{\circ} \mathrm{C}\right.$ oven for $\left.24 \mathrm{~h}\right)$. Samples were analyzed for Kjeldahl nitrogen (AOAC, 1990), ether extract (AOAC, 1990), calcium and phosphorus (AOAC, 1990), and percent ash (AOAC, 1990). Both NDF (Van Soest et al., 2001) and ADF were analyzed using an Ankom fiber analyzer (Ankom Technology, Fairport, NY). Heat-stable $\alpha$-amylase (A3306; Sigma Chemical Co., St. Louis, MO) was included in the NDF procedure (100 $\mu \mathrm{L} / 0.50 \mathrm{~g}$ of sample). Body weight and 
Table 2. Ingredient and chemical composition of early dry and closeup total mixed $\operatorname{diets}^{1}$ (DM basis)

\begin{tabular}{|c|c|c|c|c|}
\hline \multirow[b]{2}{*}{ Diet } & \multicolumn{2}{|c|}{ Early dry } & \multicolumn{2}{|c|}{ Close-up } \\
\hline & Control & WCGF & Control & WCGF \\
\hline \multicolumn{5}{|l|}{ Ingredient, \% } \\
\hline Grass hay $^{2}$ & 31.7 & 28.0 & 28.5 & 26.1 \\
\hline Corn silage & 45.6 & 40.1 & 41.1 & 37.4 \\
\hline Corn gluten feed & - & 29.9 & - & 30.0 \\
\hline Ground corn & 9.4 & - & 11.5 & - \\
\hline Soybean hulls & 2.4 & - & 4.0 & - \\
\hline Limestone & 0.72 & 0.89 & 1.0 & 1.2 \\
\hline Soybean meal, $48 \% \mathrm{CP}$ & 9.6 & 0.64 & 13.6 & 4.8 \\
\hline Salt & 0.06 & 0.11 & - & - \\
\hline Sel-Plex $1000^{3}$ & 0.04 & 0.04 & 0.04 & 0.04 \\
\hline Mineral-vitamin premix ${ }^{4}$ & 0.26 & 0.26 & 0.39 & 0.39 \\
\hline \multicolumn{5}{|l|}{ Composition, \% } \\
\hline $\mathrm{DM}$ & 50.1 & 48.6 & 52.4 & 50.0 \\
\hline $\mathrm{CP}$ & 14.0 & 14.0 & 15.3 & 15.4 \\
\hline Soluble CP, \% of CP & 24.4 & 39.1 & 22.7 & 36.5 \\
\hline Starch & 24.3 & 20.1 & 25.1 & 19.4 \\
\hline $\mathrm{NDF}$ & 46.6 & 49.7 & 43.9 & 49.2 \\
\hline $\mathrm{ADF}$ & 31.8 & 24.6 & 24.5 & 23.7 \\
\hline Ether extract & 2.84 & 2.70 & 2.79 & 2.63 \\
\hline $\mathrm{NFC}^{5}$ & 29.0 & 25.4 & 31.0 & 24.8 \\
\hline Ash & 7.92 & 8.24 & 7.15 & 8.08 \\
\hline $\mathrm{Ca}$ & 0.55 & 0.56 & 0.65 & 0.63 \\
\hline $\mathrm{Mg}$ & 0.19 & 0.27 & 0.20 & 0.28 \\
\hline $\mathrm{P}$ & 0.27 & 0.45 & 0.29 & 0.47 \\
\hline $\mathrm{K}$ & 1.57 & 1.54 & 1.57 & 1.62 \\
\hline
\end{tabular}

${ }^{1}$ Control treatment: ration containing no wet corn gluten feed (WCGF); WCGF: ration containing WCGF.

${ }^{2}$ Contained $12.1 \% \mathrm{CP}, 36.4 \%$ soluble $\mathrm{CP}$ (\% of $\mathrm{CP}$ ), $37.8 \% \mathrm{ADF}$, $67.1 \%$ NDF, $4.3 \%$ lignin, $2.4 \%$ fat, and $12.7 \%$ ash.

${ }^{3}$ Dietary selenium supplement (Alltech, Inc., Nicholasville, KY).

${ }^{4}$ Formulated to contain $1.0 \% \mathrm{Ca}, 0.50 \% \mathrm{P}, 0.36 \% \mathrm{Mg}$, and $1.3 \% \mathrm{~K}$, and to provide $120,000 \mathrm{IU} / \mathrm{d}$ of vitamin A, 24,000 IU/d of vitamin D, and $800 \mathrm{IU} / \mathrm{d}$ of vitamin $\mathrm{E}$ in the total ration.

${ }^{5}$ Calculated by the difference $100-(\% \mathrm{NDF}+\% \mathrm{CP}+\%$ fat $+\%$ ash).

BCS (scale of 1 to 5) were measured at 60 (dry) and $21 \mathrm{~d}$ (close-up) before expected calving, immediately after calving, and weekly during lactation (Table 4). The BCS was measured by a single trained individual and differed from that described by Wildman et al. (1982) in being reported to the quarter point. Milk production was measured daily and milk samples were collected monthly during the a.m. and p.m. milkings and were preserved using 2-bromo-2-nitropropane-1,3 diol. Daily DMI and milk yields were averaged weekly. Milk samples were analyzed for fat and true protein (AOAC, 1990) using a B2000 infrared analyzer (Bentley Instruments, Chaska, MN) by Heart of America DHIA (Manhattan, KS).

\section{Statistical Analysis}

Milk production, intake, BW, and BCS data were analyzed using the MIXED procedure of SAS, Version
Table 3. Ingredient and chemical composition of total mixed diets fed during lactation ${ }^{1}$ (DM basis)

\begin{tabular}{|c|c|c|}
\hline Diet & Control & WCGF \\
\hline \multicolumn{3}{|l|}{ Ingredient, \% } \\
\hline Alfalfa haylage $^{2}$ & 17.8 & 10.4 \\
\hline Alfalfa hay ${ }^{3}$ & 12.0 & 8.5 \\
\hline Corn silage & 29.8 & 18.9 \\
\hline Corn gluten feed & - & 37.9 \\
\hline Cottonseed & 8.7 & 5.1 \\
\hline Ground corn & 20.3 & 12.5 \\
\hline Limestone & 0.8 & 1.68 \\
\hline Soy Pass ${ }^{4}$ & 1.7 & 1.68 \\
\hline Magnesium oxide & 0.10 & - \\
\hline Soybean meal, $48 \%$ & 6.0 & 0.45 \\
\hline Blood meal & 0.62 & 0.53 \\
\hline Tallow & 0.67 & 0.74 \\
\hline Sodium bicarbonate & 0.67 & 0.76 \\
\hline Salt & 0.19 & 0.19 \\
\hline Sel-Plex $1000^{5}$ & 0.06 & 0.06 \\
\hline Vitamin premix ${ }^{6}$ & 0.12 & 0.15 \\
\hline Mineral premix ${ }^{7}$ & 0.04 & 0.04 \\
\hline Urea & 0.08 & - \\
\hline Ca:P, $23: 18 \%$ & 0.37 & - \\
\hline \multicolumn{3}{|l|}{ Composition } \\
\hline DM, \% & 51.2 & 54.4 \\
\hline $\mathrm{CP}, \%$ & 17.2 & 17.2 \\
\hline $\mathrm{RUP}^{8} \%$ of $\mathrm{CP}$ & 34.1 & 33.9 \\
\hline Soluble CP, \% of CP & 32.9 & 42.6 \\
\hline Starch, \% & 29.5 & 24.8 \\
\hline NDF, \% & 31.5 & 34.6 \\
\hline $\mathrm{ADF}, \%$ & 20.8 & 18.1 \\
\hline $\mathrm{NE}_{\mathrm{L}},{ }^{8} \mathrm{Mcal} / \mathrm{kg}$ & 1.59 & 1.56 \\
\hline Ether extract, \% & 5.45 & 4.56 \\
\hline $\mathrm{NFC},{ }^{9} \%$ & 37.4 & 34.1 \\
\hline Ash, \% & 8.32 & 9.26 \\
\hline $\mathrm{Ca}, \%$ & 0.92 & 0.95 \\
\hline $\mathrm{Mg}, \%$ & 0.29 & 0.36 \\
\hline $\mathrm{P}, \%$ & 0.38 & 0.59 \\
\hline $\mathrm{K}, \%$ & 1.46 & 1.44 \\
\hline
\end{tabular}

${ }^{1}$ Control: ration containing no amount of wet corn gluten feed (WCGF). WCGF: ration containing WCGF.

${ }^{2}$ Contained $22.0 \%$ CP, $64 \%$ soluble CP, $35 \%$ ADF, $47 \%$ NDF, $7.1 \%$ lignin, $2.5 \%$ fat, and $13.1 \%$ ash.

${ }^{3}$ Contained $24.1 \% \mathrm{CP}, 26 \%$ soluble $\mathrm{CP}$ (\% of CP), $33.2 \% \mathrm{ADF}, 46.7 \%$ NDF, $7.6 \%$ lignin, $2.0 \%$ fat, $10.2 \%$ ash.

${ }^{4}$ Bypass protein supplement (LignoTech, Overland Park, KS).

${ }^{5}$ Dietary selenium supplement (Alltech, Inc., Nicholasville, KY).

${ }^{6}$ Formulated to supply approximately $120,000 \mathrm{IU} / \mathrm{d}$ vitamin A, $24,000 \mathrm{IU} / \mathrm{d}$ of vitamin $\mathrm{D}$, and $800 \mathrm{IU} / \mathrm{d}$ of vitamin $\mathrm{E}$ in total ration.

${ }^{7}$ Formulated to contain $1.0 \% \mathrm{Ca}, 0.50 \% \mathrm{P}, 0.36 \% \mathrm{Mg}$, and $1.3 \% \mathrm{~K}$. ${ }^{8}$ According to NRC (2001).

${ }^{9}$ Calculated by difference $100-(\% \mathrm{NDF}+\% \mathrm{CP}+\%$ fat $+\%$ ash $)$.

9.1 (SAS Institute, 1999) according to the following model:

$$
\begin{aligned}
Y_{i j k l m}= & \mu+T_{i}+P_{j}+T P_{i j}+B_{k}+C_{i j k l}+W_{m} \\
& +T W_{i m}+T P W_{i j m}+\text { eijklm }
\end{aligned}
$$

where $Y_{i j k l m}$ is the dependent, continuous variable, $\mu$ is the overall mean; $T_{i}$ is the fixed effect of the $i$ th treatment $(i=1,2,3) ; P j$ is the fixed effect of the $j$ th 
Table 4. Effects on BW and BCS of feeding wet corn gluten feed (WCGF) to Holstein cows from dry off through the following lactation

\begin{tabular}{|c|c|c|c|c|c|c|c|}
\hline \multirow[b]{2}{*}{ Effect } & \multicolumn{3}{|c|}{ Treatment $^{1}$} & \multirow[b]{2}{*}{$\mathrm{SE}^{2}$} & \multicolumn{3}{|c|}{$P$ value } \\
\hline & Control & WCGF-L & WCGF-DL & & Diet & Parity & Diet $\times$ parity $^{3}$ \\
\hline \multicolumn{8}{|l|}{$\mathrm{n}$} \\
\hline Primiparous & 12 & 11 & 13 & & & & \\
\hline Multiparous & 15 & 12 & 13 & & & & \\
\hline Total & 27 & 23 & 26 & & & & \\
\hline \multicolumn{8}{|l|}{ Dry $^{4}$} \\
\hline BW, kg & 673.3 & 694.6 & 657.4 & 19.1 & 0.30 & $<0.01$ & 0.36 \\
\hline $\mathrm{BCS}$ & 3.68 & 3.65 & 3.54 & 0.06 & 0.15 & 0.05 & 0.98 \\
\hline \multicolumn{8}{|l|}{ Close-up 5} \\
\hline $\mathrm{BW}, \mathrm{kg}$ & 738.9 & 748.8 & 722.3 & 16.64 & 0.50 & $<0.01$ & 0.42 \\
\hline BCS & 3.74 & 3.71 & 3.73 & 0.08 & 0.91 & 0.02 & 0.15 \\
\hline \multicolumn{8}{|l|}{ Calving ${ }^{6}$} \\
\hline BW, kg & 664.6 & 660.6 & 649.1 & 14.9 & 0.71 & $<0.01$ & 0.23 \\
\hline $\mathrm{BCS}$ & 3.58 & 3.59 & 3.63 & 0.05 & 0.68 & 0.20 & 0.55 \\
\hline \multicolumn{8}{|c|}{ Dry to close-up change ${ }^{7}$} \\
\hline $\mathrm{BW}, \mathrm{kg}$ & 59.0 & 54.1 & 62.1 & 9.0 & 0.73 & 0.22 & 0.41 \\
\hline $\mathrm{BCS}$ & $0.04^{\mathrm{a}}$ & $0.06^{\mathrm{ab}}$ & $0.17^{\mathrm{b}}$ & 0.05 & 0.06 & 0.79 & 0.11 \\
\hline \multicolumn{8}{|c|}{ Dry to calving change ${ }^{8}$} \\
\hline $\mathrm{BW}, \mathrm{kg}$ & -13.57 & -32.96 & -10.60 & 11.8 & 0.29 & 0.04 & 0.97 \\
\hline BCS & $-0.11^{\mathrm{a}}$ & $-0.04^{\mathrm{a}}$ & $0.07^{\mathrm{b}}$ & 0.062 & 0.02 & 0.26 & 0.65 \\
\hline \multicolumn{8}{|l|}{ Lactation $^{9}$} \\
\hline BW, kg & 617.9 & 645.4 & 621.9 & 13.76 & 0.29 & $<0.01$ & 0.71 \\
\hline BCS & 3.33 & 3.36 & 3.34 & 0.04 & 0.84 & 0.20 & 0.52 \\
\hline
\end{tabular}

${ }^{\mathrm{a}, \mathrm{b}}$ Means in the same row with different superscripts differ $(P<0.05)$.

${ }^{1}$ Control treatment: animals fed diets containing no WCGF; WCGF-L: animals fed a ration containing WCGF during lactation only; WCGF-DL: animals fed rations containing WCGF during both the dry period and lactation.

${ }^{2}$ Highest standard error (SE) of treatment means is shown.

${ }^{3}$ Diet $\times$ parity $=$ diet by parity interaction.

${ }^{4}$ Dry period BW and BCS were obtained from every cow approximately $60 \mathrm{~d}$ prepartum.

${ }^{5}$ Close-up period BW and BCS were obtained from every cow approximately $21 \mathrm{~d}$ prepartum.

${ }^{6}$ Calving BW and BCS were obtained from every cow the day after calving.

${ }^{7}$ Change in BW and BCS is the difference between values at the dry period and prior to the close-up period.

${ }^{8}$ Change in BW and BCS is the difference between values at the dry period and subsequent calving.

${ }^{9} \mathrm{BW}$ and BCS during lactation (1 - 305 DIM).

parity $(i=1, \geq 2) ; T P_{i j}$ is the fixed effect of the $i$ th treatment by $j$ th parity; $B_{k}$ is the random effect of the $k$ th year $(k=1,2) ; C_{i j l}$ is the random effect of the $l$ th cow within the $i$ th treatment, within the $j$ th parity, and within the $k$ th year $(1=1, \ldots, n i j k) ; W_{m}$ is the fixed effect of the $m$ th week of the experiment $(m=1, \ldots$ 43); $T W_{i m}$ is the fixed effect of the $i$ th treatment by the $m$ th week of experimental interaction; $T P W_{i j m}$ is the fixed effect of the $i$ th treatment by the $j$ th parity by the $m$ th week of experimental interaction; and eijklm is the residual error.

The 3.5\% FCM production, milk fat, and milk protein content and yield data were analyzed using the MIXED procedure of SAS (Version 9.1; SAS Institute, 1999) according to the following model:

$$
\begin{gathered}
Y_{i j k l m}=\mu+T_{i}+P_{j}+T P_{i j}+B_{k}+C_{i j k l} \\
+M_{m}+T M_{i m}+T P M_{i j m}+e i j k l m
\end{gathered}
$$

where $Y_{i j k l m}$ is the dependent, continuous variable; $\mu$ is the overall mean; $T_{i}$ is the fixed effect of the $i$ th treatment $(i=1,2,3) ; P_{j}$ is the fixed effect of the $j$ th parity $(i=1, \geq 2) ; T P_{i j}$ is the fixed effect of the $i$ th treatment by the $j$ th parity; $B_{k}$ is the random effect of the $k$ th year $(k=1,2) ; C_{i j l}$ is the random effect of the $l$ th cow within the $i$ th treatment, within the $j$ th parity, and within the $k$ th year $(l=1, \ldots, n i j k) ; M_{m}$ is the fixed effect of the $m$ th test month experiment $(m=1, \ldots$, 43); $T M_{i m}$ is the fixed effect of the $i$ th treatment by the $m$ th test month of experimental interaction; $T P M_{i j m}$ is the fixed effect of the $i$ th treatment by the $j$ th parity 
by the $m$ th test month of experimental interaction; and eijklm is the residual error.

In the preceding models, the random effect of cow within-treatment subclasses was used as the error term for the effect of treatments. Residual errors [which are errors within cow across time and represent error from repeated measurements in the experimental unit (cow)] were modeled using a compound symmetry covariance structure. Overall treatment differences were examined using least squares means (LSMEANS). Significance was declared at $P \leq 0.05$. A trend in the data was declared at $0.05<P \leq 0.10$ and was used only for interpretation of the data. The DIFF option was used to test treatment differences among LSMEANS, and the SLICE option was used to analyze differences among weekly treatment means.

The lactation curve for each cow was described using the Wood incomplete gamma function: $y_{t}=a t^{b} e^{-c t}$ (Wood, 1967), where $y_{t}$ is milk production at time $t ; a$, $b$, and $c$ are parameters describing curve shape; and $e$ is the base of the natural logarithm. Estimated parameters were obtained using the NLIN procedure of SAS (Saxton, 2004). Parameter $a$ is milk production at the beginning of lactation; $b$ is the slope before peak (prepeak) milk production; and $c$ is the slope after peak (postpeak) milk production. According to the Wood model, lactation reaches a maximum at time $t=b / c$, with an expected production of $a(b / c)^{b} \exp ^{-b}$. Persistence was estimated as $s=-(b+1) \ln c$. The effects of diet, parity, and parity $\times$ diet interaction on each Wood parameter and estimate were tested using the following model:

$$
Y_{i j k l}=\mu+T_{i}+P_{j}+T P_{i j}+B_{k}+C_{i j k l}+e i j k l
$$

where $Y_{i j k l m}$ is the dependent variable, $\mu$ is the overall mean; $T_{i}$ is the fixed effect of the $i$ th treatment $(i=1$, $2,3) ; P_{j}$ is the fixed effect of the $j$ th parity $(i=1, \geq 2)$; $T P_{i j}$ is the fixed effect of the $i$ th treatment by the $j$ th parity; $B_{k}$ is the random effect of the $k$ th year $(k=1$, 2 ); $C_{i j l}$ is the random effect of the $l$ th cow within the $i$ th treatment, within the $j$ th parity, and within the $k$ th year $(1=1, \ldots, n i j k)$; and eijkl is the residual error.

The effect of dietary treatment on the categorical responses related to health was tested using the GENMOD procedure of SAS (SAS Institute, 1999). The statistical model included the fixed effects of diet, parity, and year.

\section{RESULTS AND DISCUSSION}

\section{Ration Composition}

The WCGF contained $40 \%$ moisture and contained $25.6 \% \mathrm{CP}, 33.6 \% \mathrm{NDF}, 10.0 \% \mathrm{ADF}, 29.7 \% \mathrm{NFC}$, and
$3.53 \%$ ether extract (DM basis; Table 1). The control diets fed during the early dry and close-up periods contained 77 and $67 \%$ forage, respectively. Both the early dry and close-up treatment diets were formulated to contain 30\% WCGF (DM basis) by replacing ground corn, soybean hulls, and a portion of the soybean meal (Table 2). The chemical compositions of the control and treatment diets fed during the early dry period were similar (Table 2), containing approximately $14 \% \mathrm{CP}$, but the WCGF diet contained approximately $4 \%$ less starch, $3 \%$ more NDF, and $0.18 \%$ more phosphorus (DM basis). As in the early dry period, diets fed during the close-up period contained similar amounts of protein (15\%), but the WCGF diet contained approximately 6\% less starch, $5 \%$ more NDF, and $0.18 \%$ more phosphorus (DM basis). The control diets fed during lactation contained $60 \%$ forage, which was $22 \%$ more forage than the WCGF treatment diet. The WCGF treatment diet was formulated to contain $40 \%$ WCGF (DM basis) by reducing the amount of forage by 22 percentage units and the amount of concentrate by 17 percentage units (Table 3 ). The diet fed during lactation contained similar amounts of protein (17\%), but the WCGF diet contained approximately $5 \%$ less starch, $3 \%$ more NDF, and $0.21 \%$ more phosphorus (DM basis).

\section{$B W$ and $B C S$}

Body weight and BCS were measured at 60 (dry) and $21 \mathrm{~d}$ (close-up) before expected calving as well as immediately after calving (Table 4). Neither BW nor BCS were affected by dietary treatment during these periods. However, the change in BCS between 60 and $21 \mathrm{~d}$ before expected calving tended $(P=0.06)$ to be affected by dietary treatment. Cows fed a diet containing the WCGF during the dry and close-up periods tended to have a greater increase in BCS $(0.17 \pm 0.05)$, compared with those fed the control diet during this period (control $=0.04 \pm 0.05$ and WCGF-L $=0.06 \pm$ 0.05). Although the change in BW was not affected, numerical differences in the BW change support the same trend as those observed in the BCS change. Cows consuming the WCGF during the far-off dry and closeup periods had the highest numerical increase in BW (62.1 vs. 59.0 and $54.1 \pm 9.0 \mathrm{~kg}$ for WCGF-DL, control, and WCGF-L, respectively). Upon calving, cows consuming WCGF through the early dry and close-up periods were observed to have a slight gain in BCS $(0.07$ \pm 0.06 ). This was significantly higher than that of cows consuming the control diet, who experienced a slight loss in BCS: -0.11 and $-0.04 \pm 0.06$ for the control and WCGF-L treatments, respectively. Current industry recommendations state that cows should calve with a 
BCS of 3.25 to 3.50 and should neither gain nor lose body condition during the dry period (Contreras et al., 2004). In the current experiment, all cows had a slight gain in BCS during the far-off dry period, but cows consuming the control diet during the close-up period had a slight loss. The loss of BCS during the close-up dry period has been reported by others (Domecq et al., 1997) and is usually associated with inadequate energy intake (Dann et al., 2005; Smith et al., 2005) but does not always affect milk yield of the subsequent lactation (Ferguson, 1992). Although only a modest effect was observed, the increase in BCS in the current experiment may be an indication that diets containing WCGF may have resulted in an increase in DMI and, as a result, an improved nutritional status. The intake response in cows fed nonforage fiber sources during the prepartum feeding has been described by Pickett et al. (2003). In that experiment, cows consuming nonforage fiber sources were also observed to have a decrease in plasma NEFA - a reflection of less fat being mobilized from body fat reserves (Drackley, 1999). Because neither DMI nor NEFA were measured during the dry period, it is difficult to explain why feeding WCGF resulted in the increase in BCS during this time. However, results suggest that partial substitution of both concentrate and forage sources provided some benefit to improved body condition when fed during the dry period, possibly due to higher energy intakes.

Subsequent to calving, BW and BCS were measured weekly. Mean BCS is listed in Table 4, and weekly estimates are illustrated in Figure 1. Although feeding WCGF during the dry period resulted in improvements in the BCS, there were no treatment differences in BCS during wk 1 of lactation, which averaged $3.55 \pm$ 0.07 across treatments. This observation indicates that cows calved within the recommended range of BCS. There were no differences due to treatment on postpartum BW and BCS, which averaged $627.5 \pm 13.8$ and $3.34 \pm 0.04 \mathrm{~kg}$ across treatments and during lactation (Table 4, Figure 1). This is similar to the observations of Boddugari et al. (2001), who observed no differences in BW and BCS when WCGF was fed in place of both fiber and concentrate. Although there were no treatment differences, the lowest BCS for all treatments was between wk 7 and 10 . This result is $3 \mathrm{wk}$ later than reported by Domecq et al. (1997) but is similar to the results observed by Waltner et al. (1993). Because body condition at the end of lactation is an accurate indicator of the energy status of a cow (Dechow et al., 2004), BCS was evaluated during the last week of lactation. Although cows consuming the control diet had the lowest BCS $(3.47 \pm 0.06)$, this was not significantly different from either of the remaining treatments $(3.54 \pm 0.06$ for both WCGF-L and WCGF-DL).

\section{Intake, Milk Yield, FCM, and Milk Components}

There were no differences in either DMI or actual milk yield between WCGF-L and WCGF-DL treatments, indicating that prepartum diets did not influence lactational performance. Cows consuming rations containing the WCGF during lactation consumed significantly more feed compared with the control (Table 5, Figure 2). Actual milk production was significantly higher for cows consuming the WCGF (Table 5, Figure 3). The paired increase in DMI and milk yield resulted in a similar efficiency of milk production, with $3.5 \%$ FCM averaging 1.5 across treatments. The increase in DMI for cows consuming WCGF is in contrast to the observations of Boddugari et al. (2001). These investigators observed that partial replacement of the WCGF for concentrate and forage, or $40 \%$ of the diet DM, resulted in cows consuming less feed but producing more than $5 \mathrm{~kg}$ more milk. It is difficult to speculate on the reasons for the discrepancy between these studies, especially considering the similarity in diets. Nevertheless, the increase in DMI is not surprising, given that intake is influenced by feed particle size and digesta passage rate (Beauchemin and Yang, 2005), which has been demonstrated to increase in diets containing WCGF (Boddugari et al., 2001).

The Wood model, which uses an incomplete gamma function, was used to describe the lactation curve of each individual cow. The shapes of the lactation curves were similar across treatments, as no differences were found on parameters $a$ (initial milk yield), $b$ (slope prepeak), and $c$ (slope postpeak; see Table 6). Time to peak milk production was similar across treatments, averaging $20 \pm 2.7$ wk. Peak milk production tended to be affected by dietary treatment. Specifically, peak milk production was lowest in cows consuming the control diet $(36.2 \pm 2.27 \mathrm{~kg})$ and higher in cows consuming the WCGF diet during lactation $(40.1 \pm 2.27 \mathrm{~kg})$ and during the dry period and lactation $(39.8 \pm 2.27$ $\mathrm{kg})$. Although feeding WCGF during the dry period resulted in an increase in BCS, there were no differences in milk production during early lactation. Specifically, the slope of the lactation curve prepeak (b) and the level of peak milk were similar for WCGF-L and WCGF-DL. This indicates that although cows were fed different diets during the dry period, feeding WCGF during this time did not result in differences in milk production during early lactation. Persistence was similar across treatments, averaging 5.32; this response is consistent with previous findings (Boddugari et al., 2001). In an experiment conducted over 15 


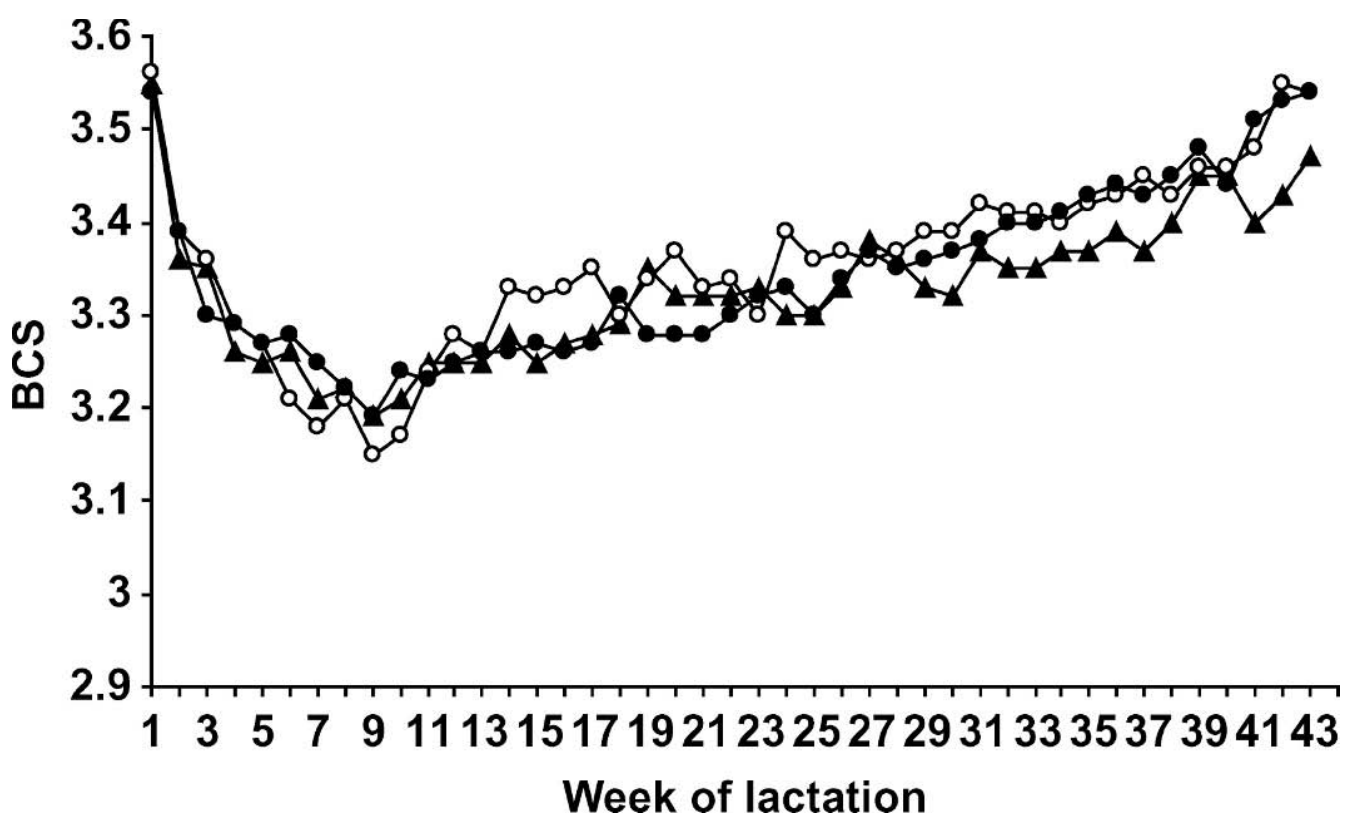

Figure 1. Body condition score of cows fed $(\boldsymbol{\Delta})$ the control diet [no wet corn gluten feed (WCGF)], $(\bigcirc)$ WCGF during lactation only (WCGF-L), and (-) WCGF during both the dry period and lactation (WCGF-DL). Means for the respective treatments over the entire lactation were $3.33,3.36$, and $3.34 \mathrm{~kg} / \mathrm{d}$ (SE $0.04, P=0.84)$; no effect of parity was observed $(P=0.20)$, and no interaction between diet and parity was observed $(P=0.52)$.

wk of lactation, Schroeder (2003) observed a quadratic response on DMI and FCM yield when WCGF was used to replace forage and barley grain at 15, 30, and $45 \%$ of the diet DM. In this experiment, both intake and milk yield increased when WCGF was fed at 15 and $30 \%$ of the diet DM, but when diets contained $45 \%$, no differences were observed when compared with the control. The increase in milk yield reported previously (Boddugari et al., 2001) was attributed to the improvement in nutrient digestibility. Unfortunately, data from the current study do not allow inferences regard- ing rumen fermentation or total diet digestibility and effects on milk yield, but this reason remains plausible. Nevertheless, diets containing WCGF were consumed in the greatest amounts, thus supplying more energy for milk production. This result supports the observations of others who evaluated the effects of feeding WCGF to lactating dairy cows (VanBaale et al., 2001).

Inclusion of the WCGF also resulted in reducing the concentration of milk fat; however, since total milk yield was increased, no differences were observed in

Table 5. Effects of feeding wet corn gluten feed (WCGF) to Holstein cows from dry off through lactation

\begin{tabular}{|c|c|c|c|c|c|c|c|}
\hline \multirow[b]{2}{*}{ Effect } & \multicolumn{3}{|c|}{ Treatment $^{1}$} & \multirow[b]{2}{*}{$\mathrm{SE}^{2}$} & \multicolumn{3}{|c|}{$P$ value } \\
\hline & Control & WCGF-L & WCGF-DL & & Diet & Parity & Diet $\times$ parity $^{3}$ \\
\hline $\mathrm{DMI}, \mathrm{kg} / \mathrm{d}$ & $21.2^{\mathrm{b}}$ & $25.4^{\mathrm{a}}$ & $23.8^{\mathrm{a}}$ & 0.8 & $<0.01$ & $<0.01$ & 0.62 \\
\hline Milk yield, $\mathrm{kg} / \mathrm{d}$ & $31.1^{\mathrm{b}}$ & $35.0^{\mathrm{a}}$ & $34.7^{\mathrm{a}}$ & 2.1 & 0.03 & $<0.01$ & 0.27 \\
\hline $3.5 \% \mathrm{FCM}, \mathrm{kg} / \mathrm{d}$ & $34.7^{\mathrm{b}}$ & $38.9^{\mathrm{a}}$ & $36.3^{\mathrm{ab}}$ & 1.9 & 0.10 & 0.04 & 0.58 \\
\hline Fat, \% & $4.15^{\mathrm{a}}$ & $3.94^{\mathrm{ab}}$ & $3.74^{\mathrm{b}}$ & 0.08 & $<0.01$ & 0.33 & 0.47 \\
\hline Fat yield, kg/d & 1.30 & 1.43 & 1.30 & 0.07 & 0.14 & 0.08 & 0.78 \\
\hline Protein, \% & 3.19 & 3.17 & 3.16 & 0.04 & 0.80 & 0.66 & 0.39 \\
\hline Protein yield, kg/d & $1.00^{\mathrm{b}}$ & $1.15^{\mathrm{a}}$ & $1.10^{\mathrm{ab}}$ & 0.06 & 0.03 & 0.04 & 0.64 \\
\hline Milk/DMI, kg/kg & 1.50 & 1.43 & 1.55 & 0.09 & 0.39 & 0.22 & 0.26 \\
\hline
\end{tabular}

${ }^{\mathrm{a}, \mathrm{b}}$ Means in the same row with different superscripts differ $(P<0.05)$.

${ }^{1}$ Control treatment: animals fed diets containing no WCGF; WCGF-L: animals fed a ration containing WCGF during lactation only; WCGF-DL: animals fed rations containing WCGF during both the dry period and lactation.

${ }^{2}$ Highest standard error (SE) of treatment means is shown.

${ }^{3}$ Diet $\times$ parity $=$ diet by parity interaction. 


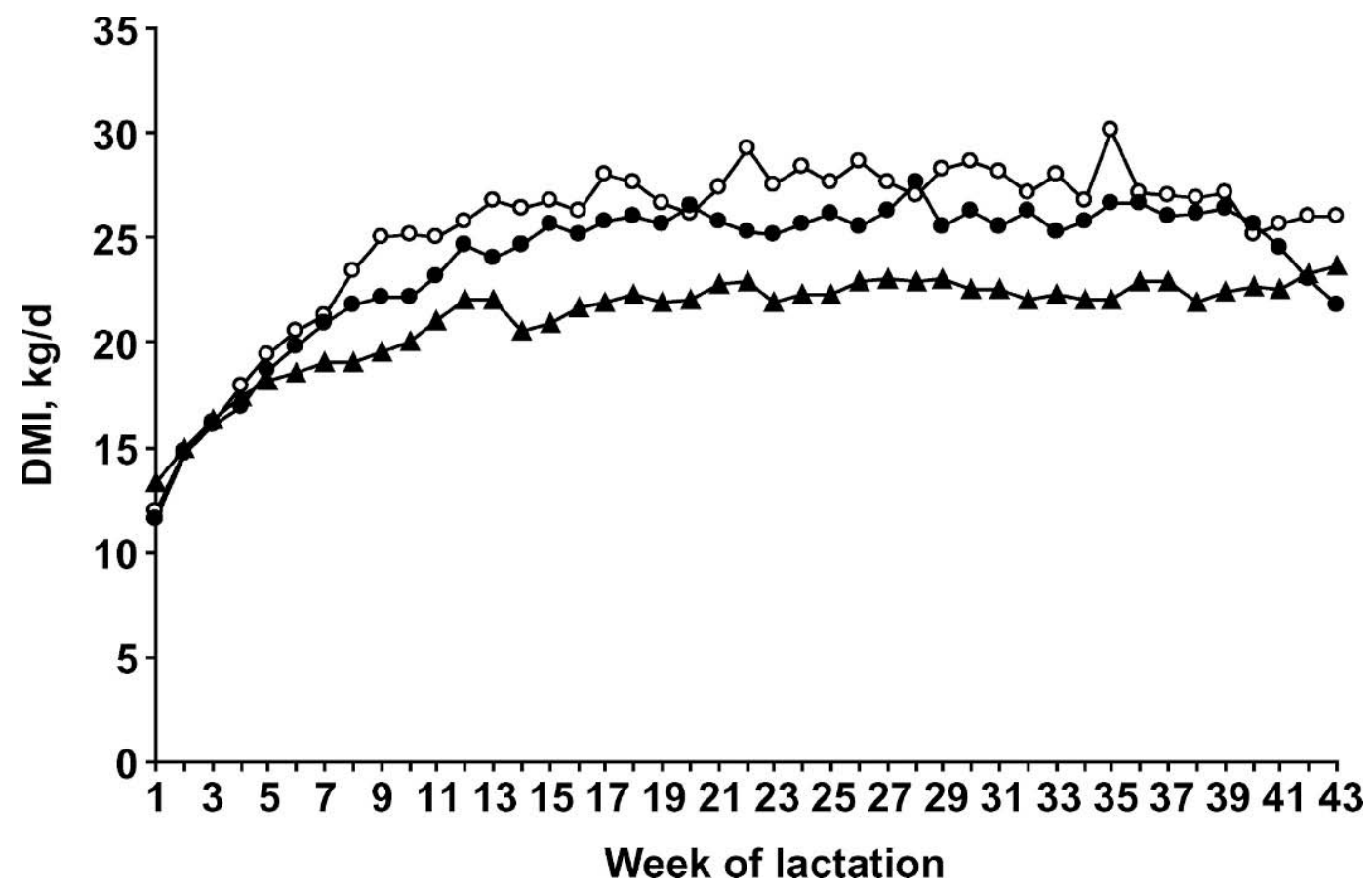

Figure 2. Dry matter intake of cows fed (A) the control diet [no wet corn gluten feed (WCGF)], (O) WCGF during lactation only (WCGFL), and (-) WCGF during both the dry period and lactation (WCGF-DL). Means for the respective treatments over the entire lactation were $21.1,25.4$, and $23.8 \mathrm{~kg} / \mathrm{d}(\mathrm{SE}=0.73, P<0.01)$; a significant effect of parity was observed $(P<0.01)$, but no interaction between diet and parity was observed $(P=0.62)$.

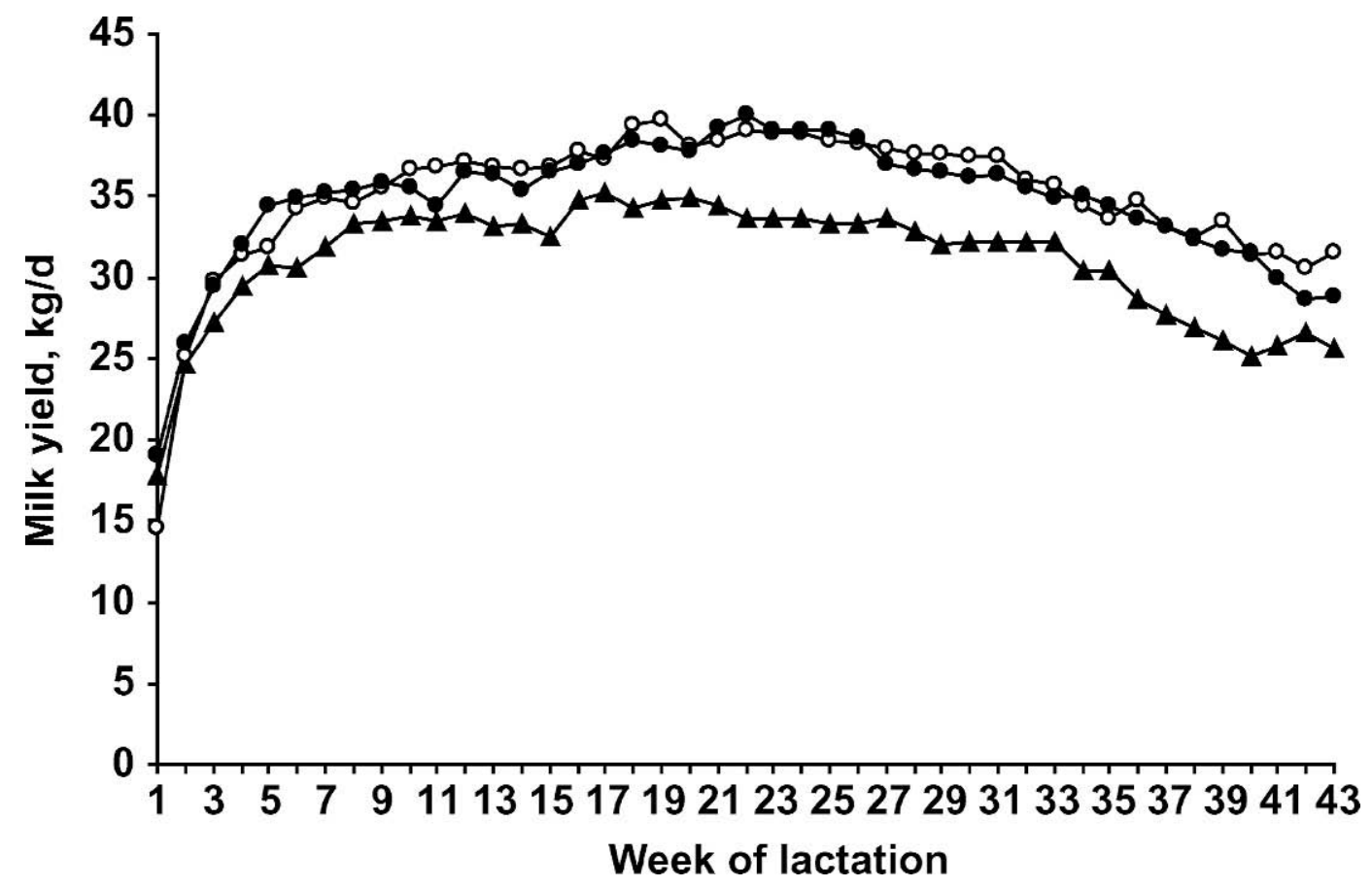

Figure 3. Lactation curves of cows fed (A) the control diet [no wet corn gluten feed (WCGF)], (O) WCGF during lactation only (WCGFL), and ( WCGF during both the dry period and lactation (WCGF-DL). Means for the respective treatments over the entire lactation were $31.1,35.0$, and $34.7 \mathrm{~kg} / \mathrm{d}(\mathrm{SE}=2.1, P=0.03)$; a significant effect of parity was observed $(P<0.01)$, but no interaction between diet and parity was observed $(P=0.27)$. 
Table 6. Effects of feeding wet corn gluten feed (WCGF) to Holstein cows on time to peak production, peak milk production, and persistence

\begin{tabular}{|c|c|c|c|c|c|c|c|}
\hline \multirow[b]{2}{*}{ Parameter } & \multicolumn{3}{|c|}{ Treatment $^{1}$} & \multirow[b]{2}{*}{$\mathrm{SE}^{2}$} & \multicolumn{3}{|c|}{$P$ value } \\
\hline & Control & WCGF-L & WCGF-DL & & Diet & Parity & Diet $\times$ parity $^{3}$ \\
\hline$a$, initial milk yield, $\mathrm{kg}$ & 18.5 & 19.3 & 20.5 & 2.8 & 0.60 & $<0.01$ & 0.45 \\
\hline$b$, slope prepeak, kg/wk & 0.44 & 0.42 & 0.39 & 0.05 & 0.78 & 0.63 & 0.78 \\
\hline$c$, slope postpeak, $\mathrm{kg} / \mathrm{wk}$ & 0.028 & 0.032 & 0.023 & 0.005 & 0.29 & 0.29 & 0.29 \\
\hline Time to peak, ${ }^{4} \mathrm{wk}$ & 19.9 & 20.9 & 19.3 & 2.7 & 0.91 & 0.02 & 0.22 \\
\hline Peak milk, ${ }^{5} \mathrm{~kg}$ & $36.2^{\mathrm{b}}$ & $40.1^{\mathrm{a}}$ & $39.8^{\mathrm{ab}}$ & 2.3 & 0.08 & $<0.01$ & 0.05 \\
\hline Persistence $^{6}$ & 5.35 & 5.27 & 5.35 & 0.17 & 0.91 & $<0.01$ & 0.14 \\
\hline
\end{tabular}

${ }^{\mathrm{a}, \mathrm{b}}$ Means in the same row with different superscripts differ $(P<0.05)$.

${ }^{1}$ Control treatment: animals fed diets containing no WCGF; WCGF-L: animals fed a ration containing WCGF during lactation only; WCGF-DL: animals fed rations containing WCGF during both the dry period and lactation.

${ }^{2}$ Highest standard error (SE) of treatment means is shown.

${ }^{3}$ Diet $\times$ parity $=$ diet by parity interaction.

${ }^{4}$ Time, $t=b / c$.

${ }^{5}$ Expected peak production $=a(b / c)^{b} \exp ^{-b}$.

${ }^{6}$ Persistence $=-(b+1) \ln c$.

total milk fat yield. These findings are in contrast with those of Boddugari et al. (2001) but are similar to those of VanBaale et al. (2001). Differences in the concentration of milk protein were not observed; however, since including the WCGF increased total milk yield, total protein yield was significantly higher for cows consuming the WCGF during lactation. These results are consistant with those reported by Boddugari et al. (2001) and VanBaale et al. (2001), in which milk protein yield was increased when cows were fed the WCGF. This response is possibly due to the higher feed intakes of cows consuming WCGF, as energy intake is positively correlated with milk protein synthesis (Grieve et al., 1986). Even though the increase in DMI was associated with an increase in milk production, no effect was observed on BCS. Because lipid metabolism of body reserves is known to make up a substantial contribution to the energetic cost of milk production (Friggens et al., 2004), these results indicate that the increase in milk yield was supported by an increase in DMI and did not result in an excessive depletion of energy reserves.

\section{Health and Reproduction Records}

Cow health and reproduction records are listed in Table 7. Compared with other studies evaluating health and reproduction (Windig et al., 2005), the current study contained a small number of animals and should be interpreted with caution. Table 7 lists the

Table 7. Effects on health disorders of feeding wet corn gluten feed (WCGF) to Holstein cows from dry off through lactation

\begin{tabular}{|c|c|c|c|c|c|}
\hline \multirow[b]{2}{*}{ Disorder } & \multicolumn{3}{|c|}{ Treatment $^{1}$} & \multicolumn{2}{|c|}{$P$ value } \\
\hline & Control & WCGF-L & WCGF-DL & Diet & Parity \\
\hline No. of animals & 27 & 23 & 26 & & \\
\hline Displaced abomasum & 1 & 5 & 3 & 0.13 & 0.11 \\
\hline Metabolic disorder ${ }^{2}$ & 1 & 1 & 1 & 0.99 & 0.81 \\
\hline Mastitis & 6 & 10 & 9 & 0.23 & 0.19 \\
\hline Foot disorder ${ }^{3}$ & 7 & 5 & 8 & 0.71 & 0.39 \\
\hline Respiratory & 0 & 1 & 2 & 0.21 & 0.69 \\
\hline Services per conception 4 & 2.1 & 1.8 & 2.7 & 0.87 & 0.82 \\
\hline Number of days open ${ }^{5}$ & 154.1 & 161.6 & 209.6 & 0.89 & 0.93 \\
\hline
\end{tabular}

${ }^{1}$ Control treatment: animals fed diets containing no WCGF; WCGF-L: animals fed a ration containing WCGF during lactation only; WCGF-DL: animals fed rations containing WCGF during both the dry period and lactation.

${ }^{2}$ Includes parturient paresis and hypocalcemia.

${ }^{3}$ Includes toe abscesses, toe ulcers, and hoof rot.

${ }^{4}$ Standard error of treatment means $=22.8$.

${ }^{5}$ Standard error of treatment means $=0.82$. 
number of animals diagnosed with displaced abomasums, metabolic disorders, mastitis, foot disorders, or respiratory disorders. All observations of displaced abomasums occurred in cows early in lactation: control = 31 DIM, WCGF-L = $15+10$ DIM, and WCGF-DL $=10$ +3 DIM. Table 7 also lists the number of services per conception and total days open by dietary treatment. No significant effects of dietary treatment were observed on any health or reproductive measure. Further research should be conducted with more animals and should be designed to evaluate the effects on these measures of feeding WCGF.

\section{CONCLUSIONS}

When observed over a full lactation, cows that were fed diets that contained 40\% WCGF (DM basis) increased milk and protein yield. This effect was not dependent on animals receiving WCGF during the dry period. No differences in reproductive or health parameters were observed. It appeared that the increase in milk yield was due to an increase in DMI, which resulted in higher peak milk yields.

\section{ACKNOWLEDGMENTS}

This research was a component of a USDA, NC Regional Project (NC-1119). The authors thank the personnel at the Dairy Research Unit (Mead, NE) for care of experimental animals during the experiment. The assistance of B. Esau and B. Janicek in data entry and sample collection is much appreciated.

\section{REFERENCES}

AOAC. 1990. Official Methods of Analysis. 15th ed. Association of Official Analytical Chemists, Arlington, VA.

Armentano, L. E., and M. R. Dentine. 1988. Wet corn gluten feed as a supplement for lactating dairy cattle and growing heifers. J. Dairy Sci. 71:990-995.

Beauchemin, K. A., and W. Z. Yang. 2005. Effects of physically effective fiber on intake, chewing activity, and ruminal acidosis for dairy cows fed diets based on corn silage. J. Dairy Sci. 88:2117-2129.

Boddugari, K., R. J. Grant, R. Stock, and M. Lewis. 2001. Maximal replacement of forage and concentrate with a new wet corn milling product for lactating dairy cows. J. Dairy Sci. 84:873-884.

Contreras, L. L., C. M. Ryan, and T. R. Overton. 2004. Effects of dry cow grouping strategy and prepartum body condition score on performance and health of transition dairy cows. J. Dairy Sci. 87:517-523.

Dann, H. M., D. E. Morin, G. A. Bollero, M. R. Murphy, and J. K. Drackley. 2005. Prepartum intake, postpartum induction of ketosis, and periparturient disorders affect the metabolic status of dairy cows. J. Dairy Sci. 88:3249-3264.

Dechow, C. D., G. W. Rogers, U. Sander-Nielsen, L. Klei, T. J. Lawlor, J. S. Clay, A. E. Freeman, G. Abdel-Azim, A. Kuck, and S. Schnell. 2004. Correlations among body condition scores from various sources, dairy form, and cow health from the United States and Denmark. J. Dairy Sci. 87:3526-3533.
Domecq, J. J., A. L. Skidmore, J. W. Lloyd, and J. B. Kaneene. 1997. Relationship between body condition scores and milk yield in a large dairy herd of high yielding Holstein cows. J. Dairy Sci. 80:101-112.

Drackley, J. K. 1999. Biology of dairy cows during the transition period: The final frontier? J. Dairy Sci. 82:2259-2273.

Ferguson, J. D. 1992. Body condition scoring. Adv. Dairy Cattle Nutr. Sem., Am. Assoc. Bovine Pract. Conf., Minneapolis, MN.

Friggens, N. C., K. L. Ingvartsen, and G. C. Emmans. 2004. Prediction of body lipid change in pregnancy and lactation. J. Dairy Sci. 87:988-1000.

Grieve, D. G., S. Korver, Y. S. Rijpkema, and G. Hof. 1986. Relationship between milk composition and some nutritional parameters in early lactation. Livest. Prod. Sci. 14:239-254.

Hayirli, A., R. R. Grummer, E. V. Nordheim, and P. M. Crump. 2003. Models for predicting dry matter intake of Holsteins during the prefresh transition period. J. Dairy Sci. 86:1771-1779.

Macken, C. N., G. E. Erickson, T. J. Klopfenstein, and R. A. Stock. 2004. Effects of concentration and composition of wet corn gluten feed in steam-flaked corn-based finishing diets. J. Anim. Sci. 82:2718-2723.

National Research Council (NRC). 2001. Nutrient Requirements of Dairy Cattle. 7th rev. ed. Natl. Acad. Sci., Washington, DC.

Ordway, R. S., V. A. Ishler, and G. A. Varga. 2002. Effects of sucrose supplementation on dry matter intake, milk yield, and blood metabolites of periparturient Holstein dairy cows. J. Dairy Sci. $85: 879-888$

Pickett, M. M., T. W. Cassidy, P. R. Tozer, and G. A. Varga. 2003. Effect of prepartum dietary carbohydrate source and monensin on dry matter intake, milk production, and blood metabolites of transition cows. J. Dairy Sci. 87(Suppl. E):E105-E119.

SAS Institute. 1999. SAS User's Guide: Statistics, Version 8.2. SAS Institute, Cary, NC.

Saxton, A. M. 2004. Genetic analysis of complex traits using SAS. SAS Publ., Cary, NC.

Schingoethe, D. J., M. J. Brouk, and C. P. Birkelo. 1999. Milk production and composition from cows fed wet corn distillers grains. J. Dairy Sci. 82:574-580.

Schroeder, J. W. 2003. Optimizing the level of wet corn gluten feed in the diet of lactating dairy cows. J. Dairy Sci. 86:844-851.

Smith, K. L., M. R. Waldron, J. K. Drackley, M. T. Socha, and T. R. Overton. 2005. Performance of dairy cows as affected by prepartum dietary carbohydrate source and supplementation with chromium throughout the transition period. J. Dairy Sci. 88:255-263.

VanBaale, M. J., J. E. Shirley, E. C. Titgemeyer, A. F. Park, M. J. Meyer, R. U. Lindquist, and R. T. Ethington. 2001. Evaluation of wet corn gluten feed in diets for lactating dairy cows. J. Dairy Sci. 84:2478-2485.

Van Soest, P. J., J. B. Robertson, and B. A. Lewis. 1991. Symposium: Carbohydrate methodology, metabolism, and nutritional implications in dairy cattle. Methods for dietary fiber, neutral detergent fiber and non-starch polysaccharides in relation to animal nutrition. J. Dairy Sci. 74:3583-3597.

Waltner, S. S., J. P. McNamara, and J. K. Hiller. 1993. Relationships of body condition score to production variables in high producing Holstein dairy cattle. J. Dairy Sci. 76:3410-3419.

Wickersham, E. E., J. E. Shirley, E. C. Titemeyer, M. J. Brook, J. M. DeFrain, A. F. Park, D. E. Johnson, and R. T. Ethington. 2004. Response of lactating dairy cows to diets containing wet corn gluten feed or a raw soybean hull-corn steep liquor pellet. J. Dairy Sci. 87:3899-3911.

Wildman, E. E., G. M. Jones, P. E. Wagner, H. F. Troutt, and T. N. Lesch. 1982. A dairy cow body condition scoring system and its relationship to selected production characteristics. J. Dairy Sci. 65:495-501.

Windig, J. J., M. P. L. Calus, and R. F. Veerkamp. 2005. Influence of herd environment on health and fertility and their relationship with milk production. J. Dairy Sci. 88:335-347.

Wood, P. D. P. 1967. Algebraic model of the lactation curve. Nature 216:164-165 